\title{
Tumor Suppressive Effects of miR-124 and Its Function in Neuronal Development
}

\author{
Rikako Sanuki * (D) and Tomonori Yamamura
}

check for updates

Citation: Sanuki, R.; Yamamura, T. Tumor Suppressive Effects of miR-124 and Its Function in Neuronal Development. Int. J. Mol. Sci. 2021, 22, 5919. https://doi.org/10.3390/ ijms22115919

Academic Editor: Alessandro Pogg

Received: 27 April 2021

Accepted: 27 May 2021

Published: 31 May 2021

Publisher's Note: MDPI stays neutral with regard to jurisdictional claims in published maps and institutional affiliations.

Copyright: (C) 2021 by the authors Licensee MDPI, Basel, Switzerland. This article is an open access article distributed under the terms and conditions of the Creative Commons Attribution (CC BY) license (https:// creativecommons.org/licenses/by/ $4.0 /)$.
Department of Applied Biology, Kyoto Institute of Technology, Saga Ippongi-cho 1, Ukyo-ku, Kyoto 616-8354, Japan; b7111050@edu.kit.ac.jp

* Correspondence: sanuki@kit.ac.jp; Tel.: +81-75-873-2660

\begin{abstract}
MicroRNA-124 (miR-124) is strongly expressed in neurons, and its expression increases as neurons mature. Through DNA methylation in the miR-124 promoter region and adsorption of miR-124 by non-coding RNAs, miR-124 expression is known to be reduced in many cancer cells, especially with high malignancy. Recently, numerous studies have focused on miR-124 due to its promising tumor-suppressive effects; however, the overview of their results is unclear. We surveyed the tumor-suppressive effect of miR-124 in glial cell lineage cancers, which are the most frequently reported cancer types involving miR-124, and in lung, colon, liver, stomach, and breast cancers, which are the top five causes of cancer death. Reportedly, miR-124 not only inhibits proliferation and accelerates apoptosis, but also comprehensively suppresses tumor malignant transformation. Moreover, we found that miR-124 exerts its anti-tumor effects by regulating a wide range of target genes, most notably STAT3 and EZH2. In addition, when compared to the original role of miR124 in neuronal development, we found that the miR-124 target genes that contribute to neuronal maturation share similarities with genes that cause cancer cell metastasis and epithelial-mesenchymal transition. We believe that the two apparently unrelated fields, cancer and neuronal development, can bring new discoveries to each other through the study of miR-124.
\end{abstract}

Keywords: microRNA-124; tumor suppression; EMT; metastasis; neuronal development

\section{Introduction}

MicroRNAs (miRNAs) are short, single-stranded RNAs consisting of approximately 20 nucleotides. The first miRNA discovered was the lin-4 in Caenorhabditis elegans [1,2]. Since then, many miRNAs have been identified in many species. miRNAs play a role in regulating post-transcriptional gene expression by forming an RNA-inducible silencing complex, which binds complementarily to the $3^{\prime} \mathrm{UTR}$ of mRNAs and cleaves or represses translation of the mRNA. Genes whose expression is regulated by miRNAs are called target genes, and a single miRNA could potentially regulate thousands of target genes. Therefore, miRNAs contribute to a wide range of processes, from morphogenesis to disease development, carcinogenesis, and its progression. miRNAs that promote cancer development are called oncomirs, while miRNAs that suppress cancer development are called tumor suppressive miRNAs (ts-miRNAs). Although many ts-miRNAs exist [3,4], we are focusing on one microRNA, microRNA-124 (miR-124), which is important in neurogenesis. Elsewhere, epigenetic changes of miRNAs in cancer cells can also be useful as biomarkers; however, this is outside the scope of this text and is summarized in other literatures [5-7].

miR-124 is derived from three independent genes $(m i R-124-1, m i R-124-2$, and $m i R-124-$ 3 ), and is one of the most highly expressed miRNAs in the central nervous system [8]. It is particularly expressed in neurons and is involved in their maturation and function $[9,10]$. Aside from being extremely abundant in neurons, miR-124 is thought to also play an important role in suppressing the oncogenic transformation of normal cells in other tissues, even if the miR-124 expression level is considerably lower than that in neurons. In recent 
years, miR-124 has been increasingly reported as an miRNA with antitumor activity. However, many reports with unclear overview of their results exist. Therefore, in this review, we summarize the anti-tumor effects of miR-124. We then discuss the functions of miR-124 with that of its original role in neurons.

\section{Suppression of miR-124 Functions in Cancer Cells}

miRNAs are downregulated globally in human cancers, suggesting their role as general tumor suppressors [11]. Among them, the expression level of miR-124 is decreased in cancer cells compared to that in normal tissues, and is presumably involved in the pathogenesis of cancer. In 2007, the decreased expression of miR-124 was discovered to be caused by methylation of the CPG islands of the genomic region encoding miR-124 in colorectal cancer cells HCT-116 [12]. This finding led to the further discovery of the tumor-suppressive effect of miR-124. Genes whose expression is regulated by miRNAs are called target genes. The CDK6 gene in HCT-116 cells, which is involved in cell cycle progression, was identified as a target gene of miR-124 [12,13]. Subsequently, miR-124 expression was also found to be reduced in glioblastoma multiforme and medulloblastoma compared to normal tissues, and exogenous miR-124 expression was found to be effective in inhibiting cancer cell growth by targeting CDK6 [14,15].

The suppression of miR-124 functions in cancer cells is not limited to transcriptional regulation. Some kinds of protein non-coding RNAs have sequences complementary to miR-124 and are thought to suppress the function of miR-124 in cancer cells by adsorbing miR-124. Circular RNAs (circRNAs) have been reported to regulate cell growth by sponging multiple miRNAs, including miR-124 [16-23]. Reportedly, the circRNA, circHIPK3, which was derived from Exon2 of HIPK3 [16], contributes to cancer progression by adsorbing miR-124 in many types of cancer, including liver cancer [16,24], glioma [25-27], lung cancer [28], gastric cancer [29], gallbladder cancer [30], and oral squamous cell carcinoma [31]. In addition to circRNAs, the long non-coding RNA, metastasis-associated lung adenocarcinoma transcript-1 (MALAT1), can also adsorb miR-124 and promote non-small cell lung cancer [32,33], cervical cancer [34], and nasopharyngeal carcinoma [35], and is known to promote malignancy through increased expression of miR-124 target genes.

Thus, a great variety of cancers create a more favorable environment for tumor growth either by suppressing miR-124 expression, by adsorbing miR-124, or in combination (Figure 1).

\section{Tumor Suppressive Effects by miR-124 in Glial Lineage Cancers}

Although miR-124 is downregulated in various types of cancers and exhibits tumorsuppressive effects through overexpression, the most frequently reported cancers associated with miR-124 are those of the glial cell lineage, such as glioblastomas and astrocytomas [15,36-50]. Reportedly, expression of the target gene of miR-124 is consistent with malignancy and prognosis $[38,41,51]$. Many miR-124 target genes have been identified, including CDK6, and miR-124 can not only suppress cell proliferation and progress apoptosis but also inhibits cell invasion, metastasis, and angiogenesis by reducing the expression of the target genes. Thus miR-124 is expected to be effective in almost all processes of antitumor effects including tumor malignant transformation (Table 1). Moreover, interestingly, it has been reported that miR-124 expression affects not only the glioma stem cells but also the cancer-immune system by activating $T$ cells through the glioma stem cells [39]. Temozolomide (TMZ) is an anticancer drug that damages DNA by methylating guanine, induces cell cycle arrest, and causes cell death due to cellular stress [52]. TMZ is the first-line chemotherapeutic agent in glioblastoma, and its effect is reportedly reinforced by miR-124 [45,48]. Therefore, the combination of miR-124 with anticancer drugs is expected to be more effective in glioma chemotherapy. 


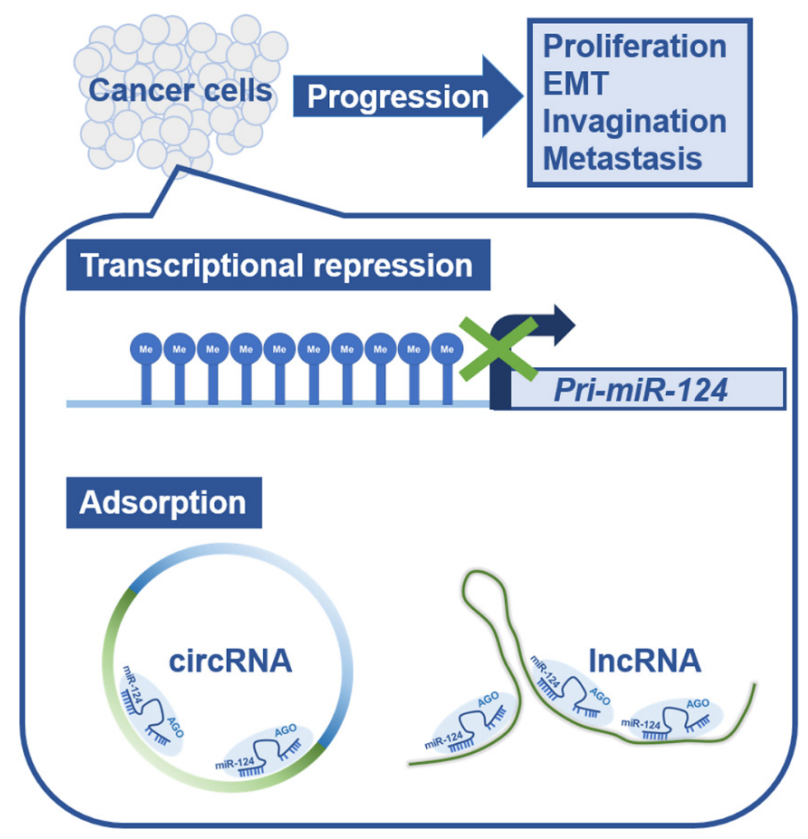

Figure 1. Schematic diagram of the mechanism of microRNA-124 functional repression in cancer cells. In human cancer cells, miRNA expression is generally downregulated, triggering the progression of cancer pathology. miR-124 transcription is repressed by methylation of CpG islands in the genomic region encoding pri-miR-124. In addition, miR-124 is adsorbed and removed by circular RNAs and long non-coding RNAs that have sequences complementary to miR-124. Abbreviations: pri-miR-124, primary microRNA-124; circRNA, circular RNA; lncRNA, long non-coding RNA; EMT, epithelial-mesenchymal transition; AGO, Argonaute.

Table 1. Anti-tumor function of microRNA-124 in glial lineage cancer.

\begin{tabular}{|c|c|c|}
\hline TARGET GENES & EFFECTS & REF. \\
\hline$A U R K A$ & $\begin{array}{l}\text { Inhibition of cell proliferation and potentiation of the } \\
\text { temozolomide TMZ-based chemosensitivity. }\end{array}$ & [45] \\
\hline CAPNS1 & Inhibition of cell migration and invasion. & [42] \\
\hline$C D K 4$ & Conferring radio-sensitivity. & [51] \\
\hline$C D K 4, C D K 6$, and $P P P 1 R 13 L$ & $\begin{array}{l}\text { Inhibition of cell migration, decrease in cell viability, and } \\
\text { cell cycle arrest at the G0/G1 phase. }\end{array}$ & [47] \\
\hline CDK6 & Induce G1 cell cycle arrest. & [15] \\
\hline CDK6 & $\begin{array}{l}\text { Decrease in cell proliferation and migration and conferring } \\
\text { chemosensitivity to TMZ. }\end{array}$ & [48] \\
\hline$C D K 6$ & Inhibition of cell proliferation. & [38] \\
\hline TEAD1, MAPK14, and SERP1 & Increase in cell death. & [41] \\
\hline $\mathrm{EZH} 2$ & $\begin{array}{l}\text { Expression of miR-124/128/137 of artificial miRNA } \\
\text { clusters, reduction of cell proliferation both in vitro and } \\
\text { in vivo, and prolongation of survival in a mouse model. }\end{array}$ & [50] \\
\hline $\begin{array}{c}\text { KITLG, NRP2, SEMA6D, and } \\
\text { THBS1 }\end{array}$ & Regulation of self-renewal, apoptosis, and invasion. & [44] \\
\hline NRP1 & $\begin{array}{c}\text { Arresting of cell cycle, inhibition of cell proliferation and } \\
\text { migration, inhibition of tumor angiogenesis, and induction } \\
\text { of apoptosis. }\end{array}$ & [49] \\
\hline PIM1 & $\begin{array}{l}\text { Inhibition of cell proliferation, invasion, and aerobic } \\
\text { glycolysis and promotion of apoptosis. }\end{array}$ & [43] \\
\hline PPP1R13L & $\begin{array}{c}\text { Inhibition of cell proliferation, G1/S transition, and } \\
\text { invasiveness. }\end{array}$ & [40] \\
\hline$S D C B P$ & $\begin{array}{l}\text { Decrease in malignancy of glioblastoma cells, inhibition of } \\
\text { cell proliferation, migration, and invasion. }\end{array}$ & [46] \\
\hline SOS1 & Inhibition of cell proliferation. & [37] \\
\hline STAT3 & $\begin{array}{l}\text { Reversing immunosuppression in the tumor } \\
\text { microenvironment, enhancing T cell-mediated immune } \\
\text { clearance, and inhibition of glioma growth. }\end{array}$ & [39] \\
\hline
\end{tabular}

TMZ: temozolomide. 


\section{Tumor Suppressive Effects of miR-124 in Major Cancers}

According to a WHO study in 2020, lung, colorectal, liver, gastric, and breast cancers account for half of all worldwide cancer deaths. Many studies and reports exist that prove miR-124 is effective against all five of these cancers.

In the pathogenesis of lung cancer, Kirsten rat sarcoma viral oncogene homologue $(K R A S)$ mutation-driven lung cancer causes increased aggressiveness and tumor size by gene ablation of the miRNA processing enzyme DICER1 [53], suggesting that miRNA functions are important for suppressing cancer. In non-small cell lung cancer (NSCLC), miR-124 suppresses cell proliferation, inhibits invasion and metastasis, and induces apoptosis [32,54-68] (Table 2).

Table 2. Anti-tumor function of miR-124 in lung cancer.

\begin{tabular}{|c|c|c|}
\hline TARGET GENES & EFFECTS & REF. \\
\hline AKT2 & $\begin{array}{l}\text { Arresting of cell cycle at the G0/G1 phase and } \\
\text { inhibition of cell growth, colony formation, and } \\
\text { tumor growth without apoptosis.Inhibition of } \\
\text { migratory and invasive abilities. }\end{array}$ & [66] \\
\hline BECN1, RELA, and SQSTM1 & $\begin{array}{c}\text { Disruption of autophagy and reduction of } \\
\text { cell survival. }\end{array}$ & [59] \\
\hline CD164 & $\begin{array}{l}\text { Inhibition of tumor cell proliferation, colony } \\
\text { formation, migration, and induction of apoptosis. }\end{array}$ & {$[58]$} \\
\hline $\mathrm{CDH} 2$ & Inhibition of cell proliferation and invasion. & [68] \\
\hline$E Z H 2$ & $\begin{array}{l}\text { Inhibition of tumor cell proliferation and inhibition } \\
\text { of the EMT process. }\end{array}$ & {$[67]$} \\
\hline LHX2 & $\begin{array}{c}\text { Attenuation of cellular migratory and } \\
\text { invasive abilities. }\end{array}$ & {$[64]$} \\
\hline MYO10 & Inhibition of migration and metastatic ability. & [61] \\
\hline SNAI2 & Inhibition of invasion. & {$[56]$} \\
\hline STAT3 & $\begin{array}{l}\text { Inhibition of cell proliferation and induction } \\
\text { of apoptosis. }\end{array}$ & {$[55]$} \\
\hline STAT3 & $\begin{array}{l}\text { Inhibition of cell growth and colony formation and } \\
\text { induction of apoptosis. }\end{array}$ & [32] \\
\hline STAT3 & $\begin{array}{c}\text { Inhibition of cell growth and colony formation and } \\
\text { induction of apoptosis. } \\
\text { Increasing radio sensitivity. }\end{array}$ & [63] \\
\hline STAT3 & $\begin{array}{l}\text { Inhibition of invasion and metastasis capacities. } \\
\text { Increasing sensitivity to cisplatin. }\end{array}$ & {$[65]$} \\
\hline TXNRD1 & $\begin{array}{l}\text { Improving sensitization of radiation-resistant cells } \\
\text { to radiation. }\end{array}$ & {$[62]$} \\
\hline ZEB1 & $\begin{array}{l}\text { Inhibition of migration and invasion through } \\
\text { suppressing EMT. }\end{array}$ & [57] \\
\hline
\end{tabular}

EMT: epithelial-mesenchymal transition.

Epithelial-mesenchymal transition (EMT) is a differentiation mechanism that results in the acquisition of undifferentiated traits during carcinogenesis. Reportedly, miR-124 suppresses EMT in NSCLC cells. According to these studies, miR-124 suppresses enhancer of zeste homolog 2 (EZH2) and zinc finger E-box binding homeobox 1 (ZEB1) [57,67], which are transcription factors that promote EMT, and also targets $\mathrm{N}$-cadherin $(\mathrm{CDH})$ [68]. Furthermore, in cells with KRAS mutations that cause EMT, miR-124 leads to cell death by suppressing autophagy, which is not observed in cancer cells with wild-type KRAS [59]. The same miR-124 target genes may or may not be targeted by miR-124 depending on the presence of KRAS mutation, which is interesting from the viewpoint of the gene targeting mechanism of miRNAs.

In colorectal cancer, miR-124 inhibits tumor formation by suppressing the proliferation of cancer cells and inhibiting metastasis [69-71]. Additionally, miR-124 expression increases oxidative stress and induces apoptosis [72]. Malignant tumors are known to have a glycolytic 
bias in glucose metabolism, known as the Warburg effect, which is thought to result from the adaptation of malignant tumors to a hypoxic environment [73]. miR-124 has also been reported to suppress the Warburg effect in a study on colorectal cancer [74] (Table 3).

Table 3. Anti-tumor function of miR-124 in colorectal cancer.

\begin{tabular}{|c|c|c|}
\hline TARGET GENES & EFFECTS & REF. \\
\hline DDX6 and PTB1 & $\begin{array}{c}\text { Induction of apoptosis. } \\
\text { Decreasing production of lactic acid, affecting the } \\
\text { Warburg effect. }\end{array}$ & {$[74]$} \\
\hline VANGL1, MYH9, and SOX9 & Inhibition of tumorigenicity. & [69] \\
\hline$P P P 1 R 13 L$ & Inhibition of cell proliferation and tumor formation. & [71] \\
\hline PTB1 & $\begin{array}{l}\text { Enhancement in oxidative stress and induction of } \\
\text { apoptosis and autophagy. }\end{array}$ & {$[72]$} \\
\hline ROCK1 & $\begin{array}{l}\text { Inhibition of cell proliferation, migration, } \\
\text { and invasion. }\end{array}$ & {$[70]$} \\
\hline STAT3 & $\begin{array}{l}\text { High-intensity focused ultrasound mediated } \\
\text { inhibition of migration. }\end{array}$ & [75] \\
\hline STAT3 & $\begin{array}{l}\text { Induction of apoptosis and inhibition of } \\
\text { tumor growth. }\end{array}$ & [76] \\
\hline
\end{tabular}

In liver cancer, miR-124 is expected to have tumor-suppressive effects, such as arrest of cell proliferation, induction of apoptosis, and inhibition of invasion and metastasis by inhibiting EMT [77-83] (Table 4). The chloride intracellular channel 1 (CLIC1) is a chloride intracellular channel, and its expression is upregulated in many cancer cells. Many studies have focused on changes in cytoskeleton-related genes in the suppression of EMT, but in liver cancer, a channel called CLIC has been identified as a target of miR-124 and is effective in suppressing metastasis and invasion [83].

Table 4. Anti-tumor function of miR-124 in liver cancer.

\begin{tabular}{|c|c|c|}
\hline TARGET GENES & EFFECTS & REF. \\
\hline CASC3 & Inhibition of tumor growth. & [81] \\
\hline CDK6, IQGAP1, SMYD3, and VIM & Inhibition of cell growth. & [77] \\
\hline CLIC1 & $\begin{array}{l}\text { Inhibition of cell proliferation, migration and } \\
\text { invasion. }\end{array}$ & [83] \\
\hline$E Z H 2$ and $R O C K 2$ & $\begin{array}{l}\text { Inhibition of cell motility and invasion, and } \\
\text { suppression of intrahepatic and pulmonary } \\
\text { metastasis. } \\
\text { Inhibition of EMT with impaired formation of } \\
\text { stress fibers, filopodia, and lamellipodia. }\end{array}$ & [79] \\
\hline ITGAV and SP1 & Inhibition of migration and tumor metastasis. & [82] \\
\hline PIK3CA & Cell cycle arrest at the G0/G1 phase. & [78] \\
\hline STAT3 & $\begin{array}{c}\text { Inhibition of cell proliferation and induction of } \\
\text { apoptosis. }\end{array}$ & [80] \\
\hline
\end{tabular}

It is known that miR-124 is also downregulated in gastric cancer cell lines, and the expression of miR-124 has been reported to inhibit growth, decrease colony-forming ability, induce apoptosis, and suppress metastasis and invasion [84-88] (Table 5). In gastric cancer cells, the transfection of miR-124 can reportedly enhance the anticancer effect of 5-fluorouracil [88]. 
Table 5. Anti-tumor function of miR-124 in gastric cancer.

\begin{tabular}{ccc}
\hline TARGET GENES & EFFECTS & REF. \\
\hline EZH2 & Inhibition of cell proliferation and colony formation and & \\
& induction of apoptosis. \\
Increased sensitization of 5-FU. & [87] \\
EZH2 and JAG1 & Inhibition of cell growth, migration, invasion, and & tumor growth. \\
ROCK1 & Inhibition of cell proliferation, migration, and invasion. & {$[86]$} \\
SPHK1 & Inhibition of cell proliferation and tumorigenicity. & {$[84]$} \\
SPHK1 & Suppression of cell proliferation and invasion. & {$[85]$} \\
\hline
\end{tabular}

miR-124 is also known to be downregulated in breast cancer cells and has been reported to have anticancer activity [89-98] (Table 6). Although apoptosis is not induced in breast cancer [90], cell cycle arrest and inhibition of invasion and metastasis are the major tumor suppressive effects of miR-124. In breast cancer cells, miR-124 expression can suppress metastasis by targeting and regulating genes that contribute to cytoskeletal dynamics, such as connective tissue growth factor (CTGF), ras homolog family member $\mathrm{G}$ (RHOG), integrin beta-1 (ITGB1), and rho-associated coiled-coil-containing protein kinase (ROCK1) [89]. Bone is a highly favorable environment for the colonization and growth of metastatic tumors, and breast cancer patients are particularly prone to skeletal metastasis. Osteolysis is triggered by cancer cells to invade the bone [99]. Reportedly, miR-124 also inhibits bone metastasis by suppressing interleukin 11 (IL11) expression in breast cancer cells, regulating osteoclastogenesis, and reducing osteolysis [96]. The mechanism of inhibiting cancer progression by regulating the differentiation of other cells through the target gene represents the diverse anticancer effects of miR-124.

Table 6. Anti-tumor function of miR-124 in breast cancer.

\begin{tabular}{|c|c|c|}
\hline TARGET GENES & EFFECTS & REF. \\
\hline AKT2 & $\begin{array}{l}\text { Inhibition of cell proliferation, migration, and } \\
\text { invasion. }\end{array}$ & [94] \\
\hline$C B L$ & Inhibition of cell proliferation and invasion. & [95] \\
\hline CD151 & $\begin{array}{l}\text { Inhibition of proliferation via cell cycle arrest but does } \\
\text { not induce apoptosis. } \\
\text { Reduction of invasive and metastatic potential. }\end{array}$ & [90] \\
\hline$C D K 4$ & Inhibition of cell proliferation. & [93] \\
\hline FLOT1 & Inhibition of cell growth and migration. & [91] \\
\hline IL11 & $\begin{array}{l}\text { Inhibition of the survival and differentiation of } \\
\text { osteoclast progenitor cells through cancer cell-derived } \\
\text { microRNA-124. }\end{array}$ & [96] \\
\hline $\begin{array}{c}\text { CTGF, ITGB1, } R H O G \text {, and } \\
\text { ROCK1 }\end{array}$ & Inhibition of metastasis. & [89] \\
\hline SNAI2 & $\begin{array}{l}\text { Inhibition of cell colony formation and } \\
\text { pulmonary metastasis. }\end{array}$ & [92] \\
\hline STAT3 & Inhibition of cell proliferation and invasion. & [97] \\
\hline STAT3 & Improving sensitization of doxorubicin. & {$[100]$} \\
\hline ZEB2 & Inhibition of cell growth and migration and EMT. & [98] \\
\hline \multicolumn{3}{|c|}{ EMT: epithelial-mesenchymal transition. } \\
\hline \multicolumn{3}{|c|}{$\begin{array}{l}\text { Thus, miR-124 has tumor-suppressive effects on various tumors, such as inhibition of } \\
\text { cell growth, invagination, migration, metastasis, invasion, and EMT. Moreover, miR-124 } \\
\text { also alters the metabolism of cancer cells, thereby suppressing the Warburg effect. It also } \\
\text { causes a decrease in autophagy function. In addition, miR-124 expression enhances the } \\
\text { efficacy of established therapies, such as improving the sensitivity of treatment-resistant } \\
\text { cancer cells (Figure 2). We believe that the effect of miR-124 will have a positive impact }\end{array}$} \\
\hline
\end{tabular}


on cancer immunotherapy as well, spreading to the cells surrounding the cancer cells expressing miR-124.

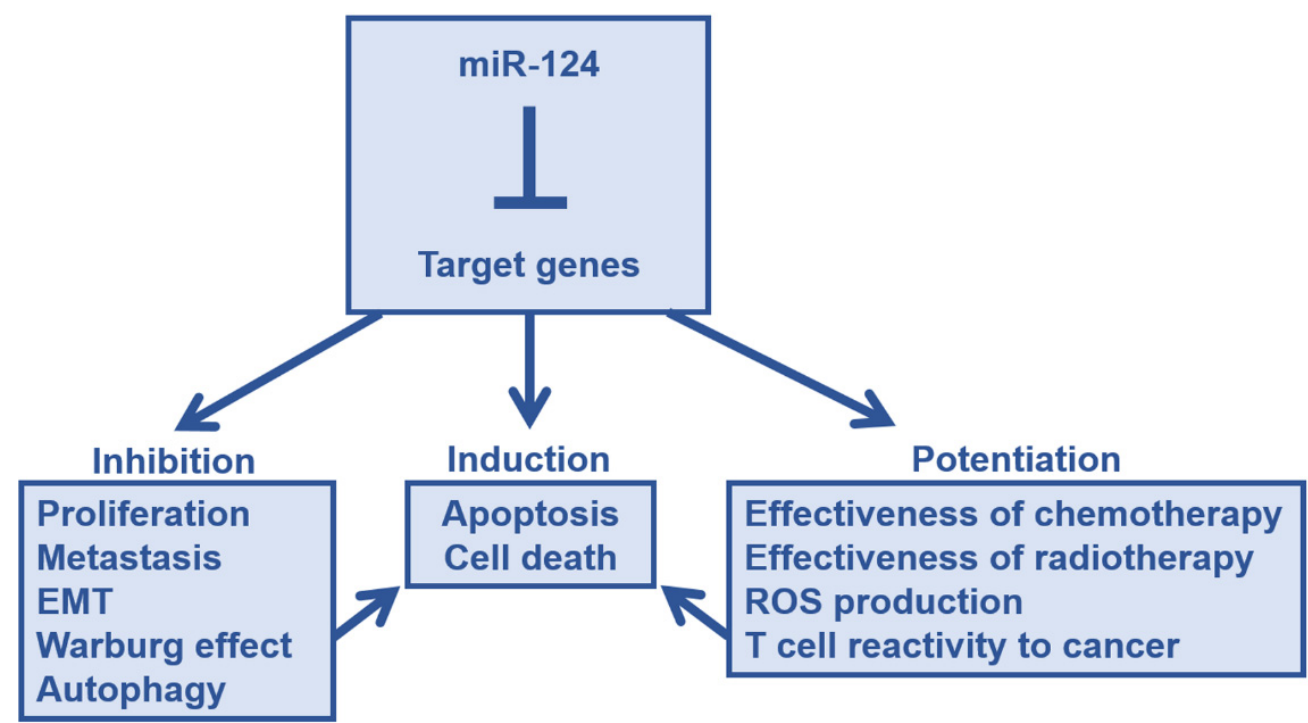

Figure 2. The antitumor effect of microRNA-124. Through the suppression of target gene expression, miR-124 prevents cancer progression and enhances therapeutic effects. These factors collectively lead to direct tumor suppression effects, such as cancer cell death. Abbreviations: ROS, reactive oxygen species; EMT, epithelial-mesenchymal transition.

\section{Target Genes Responsible for the Tumor Suppressor Effect of miR-124, STAT3, and $E Z H 2$}

The detailed mechanism of gene targeting by miRNAs remains unclear, and the same target gene may be targeted, or not targeted, in different cell types [59]. Therefore, we examined the target genes of miR-124 commonly responsible for tumor suppression in many cancer cells.

Among the many target genes of miR-124, signal transducer and activator of transcription 3 (STAT3) is the most popular gene shared by many types of cancer cells and is reportedly a target gene in glioma [39], lung cancer [32,55,63,65], colorectal cancer [75,76], hepatocellular carcinoma [80], breast cancer [97,100], endometrial cancer [101], esophageal cancer [102,103], nasopharyngeal carcinoma [104], retinoblastoma [105], prostate cancer [106], and cholangiocarcinoma [107]. In gastric cancer, miR-124 and STAT3 have already been used to evaluate drug efficacy in anticancer activity [108]. STAT3 is a transcription factor that is activated by phosphorylation which in turn activates the expression of antiapoptosis-related genes [109]. Moreover, malignant transformation of cells is mediated by the activation of STAT3, and targeting STAT3-signaling reduces the susceptibility of many cell types to malignant transformation $[110,111]$. Therefore, the fact that miR-124 targets STAT3 is an excellent explanation for the molecular mechanism of the anti-tumor effect of miR-124. Note that STAT3 suppresses apoptosis, but can also promote apoptosis $[112,113]$, which may be the cause of the difference in the induction of apoptosis by miR-124 in different cancer cell types and environments.

Another frequently reported target gene of miR-124 is the enhancer of zeste homolog 2 (EZH2), which has been found in lung adenocarcinoma [67], hepatocellular carcinoma cancer [87,88], cholangiocarcinoma [107], laryngeal squamous cell carcinoma [114], multiple myeloma [115], and ovarian cancer [23]. EZH2 is reportedly essential for the proliferation of cancer cell lines and for regulating the expression of genes related to EMT [116,117]. Therefore, it is responsible for miR-124-induced tumor suppression in cell growth inhibition $[50,67,87]$ and EMT inhibition $[23,67,79,88]$. In cholangiocarcinoma, miR-124 targets both EZH2 and STAT3, and more interestingly, knockdown of EZH2 is associated with 
a decreased expression of STAT3. It has also been reported that EZH2-STAT3 causes autophagy-related death [107].

\section{Comparison with Neuronal Development, the Original Function of miR-124}

Thus far, we have summarized the tumor-suppressive effects of miR-124 in cancer cells. However, miR-124 is strongly expressed in neurons typically and plays an important role in neuronal development. In addition, the expression level of miR-124 increases with neuronal maturation $[9,118]$. Therefore, it is thought that miR-124 plays various roles at each step in the development of the nervous system. During the development of the central nervous system, nascent neurons migrate to appropriate locations during maturation to form neurocircuits and stabilize them. In addition, neurons generally do not proliferate after their fate has been determined. Considering these features, many of the genes that have been identified as molecular mechanisms involved in miR-124mediated tumor suppression are not specific to cancer cells but are also important in neuronal differentiation. Here, we linked the tumor suppressor function of miR-124 to actual neuronal development (Figure 3).

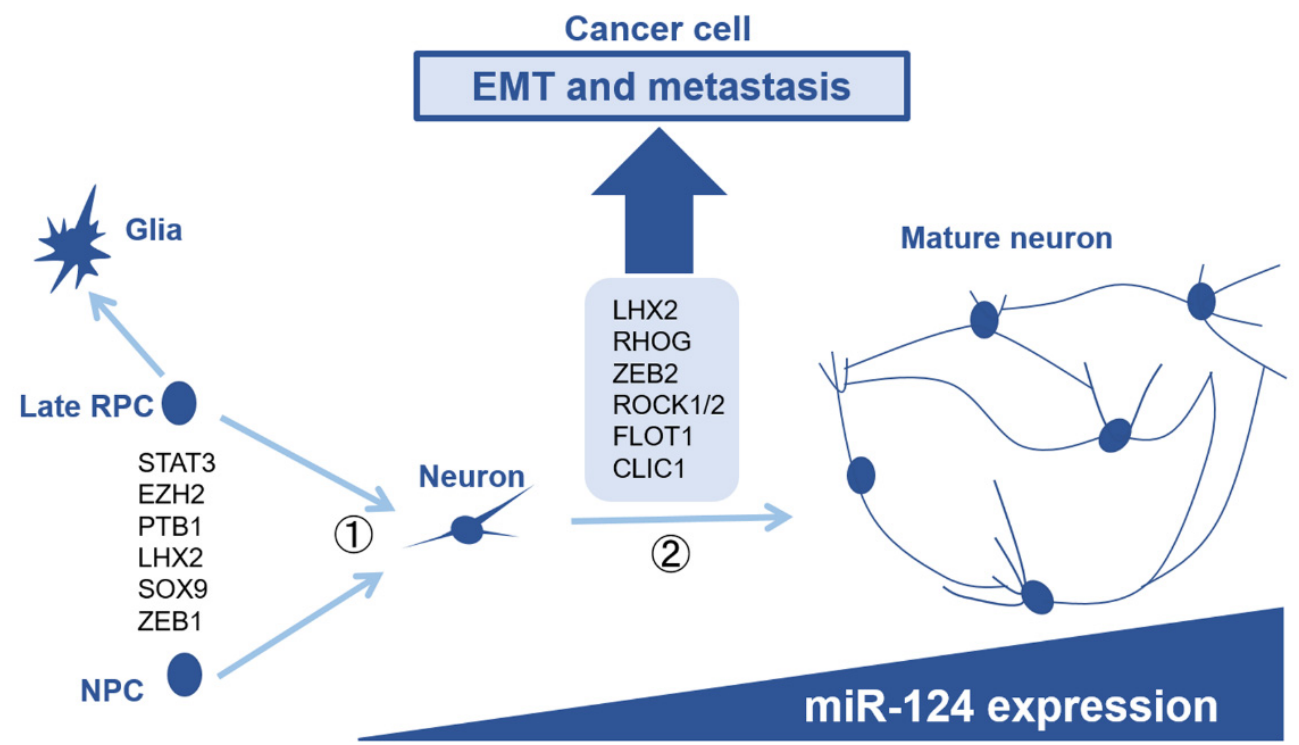

Figure 3. The role of microRNA-124 in neurogenesis and its tumor suppressive effect. miR-124 is strongly expressed in neurons, and its expression increases as the neurons mature. miR-124 is thought to act as a gatekeeper during the generation of neurons from non-neuronal cells, thus preventing the reversal of cell fate. In the process of neuronal maturation, miR-124 targets genes that contribute to proper neuronal migration, neurite formation, and synapse formation. Genes that contribute to neuronal maturation also contribute to EMT and metastasis in cancer cells. Abbreviations: RPC, retinal progenitor cell; NPC, neural progenitor cell; EMT, epithelial-mesenchymal transition.

During brain development, neurons are derived from neural progenitor cells called radial glia. In contrast, in the retina, both neurons and glial cells are produced from common retinal progenitor cells. STAT3 is an important target gene of miR-124 for its tumor suppressor effect, while in nervous system development, it is known to contribute to astrocyte differentiation [119]. In addition, P19 cells, an embryonic-derived teratoma cell line, can also differentiate into neurons and astrocytes. miR-124 reportedly targets $E Z H 2$ to allow differentiation of P19 cells into neurons and suppresses their differentiation into astrocytes [120]. Therefore, miR-124 is also thought to play a role in suppressing glial cell differentiation. Overexpression of miR-124 in mouse retinal progenitor cells decreases the percentage of glial cell differentiation and increases the percentage of neuronal differentiation [121]. Thus, it is possible that STAT3 and EZH2 are also targeted in the active fate determination of neurons from retinal progenitor cells in actual in vivo conditions. 
Furthermore, overexpression of miR-124 can induce the conversion of non-neuronal cells to neurons [122]. As well as Ezh2 [123], among the target genes of miR-124 in cancer cell, polypyrimidine tract-binding protein 1 (Ptbp1; PTB1 gene in humans) is known to be associated with such an effect [124]. PTBP1/PTB1 regulates cell type-specific alternative splicing. In neural stem cells, PTBP1/PTB1 functions to produce non-neuronal splicing isoform proteins. Suppression of $P t b p 1$ by miR-124 results in the production of neuralspecific isoforms in mice [125]. Such a difference in splicing isoforms is also known to affect the metabolism of cancer cells. Pyruvate kinase muscles (PKMs) have two splicing isoforms, the PKM1 and PKM2. In cancer cells, especially colon cancer cells, the amount of PKM2 increases due to the regulation of splicing by PTB1, and PMK1 increases when PTB1 expression is suppressed by miR-124. This alters the metabolic pathways of cancer cells and leads to a decrease in the Warburg effect of miR-124 [74]. Although it has not been found at the present time, it may be discovered in the future that PTB1-mediated metabolic control is also important for neuronal differentiation.

Newborn neurons then undergo a maturation process. Studies on miR-124-1 knockout mice have shown that miR-124 is essential for neuronal maturation [9]. miR-124 targets LIM-homeobox domain 2 (Lhx2), which is thought to regulate neuronal maturation [9]. The transcription factor LHX2 is expressed in neural stem cells and immature neurons, and is essential for neuronal production, maturation, and normal axonal projection [126-128]. Interestingly, in NSCLC, it is reported miR-124 targets LHX2 and that its reduction is associated with inhibition of metastasis and invasion [64]. Furthermore, miR-124 reportedly targets RHOG and promotes dendritic branching during neuronal maturation [129]. In breast cancer, RHOG has been identified as a target gene of miR-124 in suppressing the metastasis of cancer cells [89]. Besides these, genes that contribute to neuronal maturation [130-133] appear to be linked to genes that contribute to malignant transformation, such as migration and invasion, in cancer cells [70,79,83,86,89,91,98] (Figure 3). Reportedly, zinc finger E-box binding homeobox 2 (ZEB2) is a target of miR-124 in breast cancer [98], and reduction of $Z E B 2$ suppresses EMT and metastasis. Although there are no clear examples regarding the important functional regulation of miR-124 to ZEB2 in neurons, we believe that targeting of ZEB2 by miR-124 is important in neuronal maturation as ZEB2 promotes axonal branching and regulates normal migration of interneurons [133].

\section{Discussion}

Each of the papers discussed in this review addresses several target genes as a mechanism for the anticancer effects of miR-124. However, since each study focuses on a unique gene, unidentified targets might be missed. We think transcriptome analysis is a necessary tool, although it may be difficult to find all of them, since repression of the target genes also occurs at the translational repression level. In addition, each single cancer cell may have different characteristics, even if they are from the same strain. Therefore, the diversity of the effects of miR-124 might be determined by analyzing it at the single-cell level. Furthermore, although there have been many reports on the anticancer effects of miR-124, it is thought that there are cancers for which miR-124 does not work. We believe that analysis of such cancers is also necessary for the application of miR-124 in the treatment of cancer.

Many experimental methods express miRNAs into cancer cells using gene transfer of pre-miRNAs by plasmid or viral vectors, and induction of these miRNAs by the Tet-ON system. For clinical methods, miRNAs themselves, or chemically modified miRNAs called miRNA mimics, packaged into nanoparticles and delivered to cancer cells for uptake may be a more realistic means of miRNA-based cancer therapy [134].

\section{Conclusions}

miR-124 showed anticancer effects in various stages of cancer progression, and was not only a replacement for existing treatment methods by itself, but also enhanced the effects of the existing treatment methods, probably due to the characteristic of miRNAs to regulate multiple target genes simultaneously. 
In this review, we compared the anticancer effects of miR-124 with its effect on neural development. Despite the different functions of anticancer and neurogenic regulation, there are many common genes between the two. This means that neurodevelopmental functions may lead to new anticancer targets and anticancer effects may lead to new and important neurodevelopmental discoveries. Both fields can be made more progressive by paying attention to each other.

Author Contributions: R.S. wrote and organized this review; T.Y. and R.S. conducted the survey of relevant kinds of literature, looked at the target genes, and made a table to show what anticancer effects miR-124 might have. All authors have read and agreed to the published version of the manuscript.

Funding: This work was supported by the Leading Initiative for Excellent Young Researchers (LEADER) initiated by MEXT, Japan, and the Japan Society for the Promotion of Science (JSPS) KAKENHI (Grant No. 18K06485 and 21K06373).

Conflicts of Interest: The authors declare no conflict of interest.

\section{References}

1. Lee, R.C.; Feinbaum, R.L.; Ambros, V. The C. elegans heterochronic gene lin-4 encodes small RNAs with antisense complementarity to lin-14. Cell 1993, 75, 843-854. [CrossRef]

2. Wightman, B.; Ha, I.; Ruvkun, G. Posttranscriptional regulation of the heterochronic gene lin-14 by lin-4 mediates temporal pattern formation in C. elegans. Cell 1993, 75, 855-862. [CrossRef]

3. Sammarco, G.; Gallo, G.; Vescio, G.; Picciariello, A.; De Paola, G.; Trompetto, M.; Curro, G.; Ammendola, M. Mast Cells, microRNAs and Others: The Role of Translational Research on Colorectal Cancer in the Forthcoming Era of Precision Medicine. J. Clin. Med. 2020, 9, 2852. [CrossRef]

4. Shah, M.Y.; Ferrajoli, A.; Sood, A.K.; Lopez-Berestein, G.; Calin, G.A. microRNA Therapeutics in Cancer-An Emerging Concept. EBioMedicine 2016, 12, 34-42. [CrossRef] [PubMed]

5. Danza, K.; Silvestris, N.; Simone, G.; Signorile, M.; Saragoni, L.; Brunetti, O.; Monti, M.; Mazzotta, A.; De Summa, S.; Mangia, A.; et al. Role of miR-27a, miR-181a and miR-20b in gastric cancer hypoxia-induced chemoresistance. Cancer Biol. Ther. 2016, 17, 400-406. [CrossRef] [PubMed]

6. Gnoni, A.; Santini, D.; Scartozzi, M.; Russo, A.; Licchetta, A.; Palmieri, V.; Lupo, L.; Faloppi, L.; Palasciano, G.; Memeo, V.; et al. Hepatocellular carcinoma treatment over sorafenib: Epigenetics, microRNAs and microenvironment. Is there a light at the end of the tunnel? Expert Opin. Ther. Targets 2015, 19, 1623-1635. [CrossRef] [PubMed]

7. Brunetti, O.; Russo, A.; Scarpa, A.; Santini, D.; Reni, M.; Bittoni, A.; Azzariti, A.; Aprile, G.; Delcuratolo, S.; Signorile, M.; et al. MicroRNA in pancreatic adenocarcinoma: Predictive/prognostic biomarkers or therapeutic targets? Oncotarget 2015, 6, 23323-23341. [CrossRef]

8. Landgraf, P.; Rusu, M.; Sheridan, R.; Sewer, A.; Iovino, N.; Aravin, A.; Pfeffer, S.; Rice, A.; Kamphorst, A.O.; Landthaler, M.; et al. A mammalian microRNA expression atlas based on small RNA library sequencing. Cell 2007, 129, 1401-1414. [CrossRef] [PubMed]

9. Sanuki, R.; Onishi, A.; Koike, C.; Muramatsu, R.; Watanabe, S.; Muranishi, Y.; Irie, S.; Uneo, S.; Koyasu, T.; Matsui, R.; et al. miR-124a is required for hippocampal axogenesis and retinal cone survival through Lhx2 suppression. Nat. Neurosci. 2011, 14, 1125-1134. [CrossRef] [PubMed]

10. Kozuka, T.; Omori, Y.; Watanabe, S.; Tarusawa, E.; Yamamoto, H.; Chaya, T.; Furuhashi, M.; Morita, M.; Sato, T.; Hirose, S.; et al. miR-124 dosage regulates prefrontal cortex function by dopaminergic modulation. Sci. Rep. 2019, 9, 3445. [CrossRef]

11. Lu, J.; Getz, G.; Miska, E.A.; Alvarez-Saavedra, E.; Lamb, J.; Peck, D.; Sweet-Cordero, A.; Ebert, B.L.; Mak, R.H.; Ferrando, A.A.; et al. MicroRNA expression profiles classify human cancers. Nature 2005, 435, 834-838. [CrossRef]

12. Lujambio, A.; Ropero, S.; Ballestar, E.; Fraga, M.F.; Cerrato, C.; Setien, F.; Casado, S.; Suarez-Gauthier, A.; Sanchez-Cespedes, M.; Git, A.; et al. Genetic unmasking of an epigenetically silenced microRNA in human cancer cells. Cancer Res. 2007, 67, 1424-1429. [CrossRef] [PubMed]

13. Grossel, M.J.; Hinds, P.W. Beyond the cell cycle: A new role for Cdk6 in differentiation. J. Cell Biochem. 2006, 97, 485-493. [CrossRef] [PubMed]

14. Pierson, J.; Hostager, B.; Fan, R.; Vibhakar, R. Regulation of cyclin dependent kinase 6 by microRNA 124 in medulloblastoma. J. Neurooncol. 2008, 90, 1-7. [CrossRef] [PubMed]

15. Silber, J.; Lim, D.A.; Petritsch, C.; Persson, A.I.; Maunakea, A.K.; Yu, M.; Vandenberg, S.R.; Ginzinger, D.G.; James, C.D.; Costello, J.F.; et al. miR-124 and miR-137 inhibit proliferation of glioblastoma multiforme cells and induce differentiation of brain tumor stem cells. BMC Med. 2008, 6, 14. [CrossRef] [PubMed]

16. Zheng, Q.; Bao, C.; Guo, W.; Li, S.; Chen, J.; Chen, B.; Luo, Y.; Lyu, D.; Li, Y.; Shi, G.; et al. Circular RNA profiling reveals an abundant circHIPK3 that regulates cell growth by sponging multiple miRNAs. Nat. Commun. 2016, 7, 11215. [CrossRef] 
17. Chen, G.; Shi, Y.; Zhang, Y.; Sun, J. CircRNA_100782 regulates pancreatic carcinoma proliferation through the IL6-STAT3 pathway. Onco Targets Ther. 2017, 10, 5783-5794. [CrossRef]

18. Wang, R.; Zhang, S.; Chen, X.; Li, N.; Li, J.; Jia, R.; Pan, Y.; Liang, H. EIF4A3-induced circular RNA MMP9 (circMMP9) acts as a sponge of miR-124 and promotes glioblastoma multiforme cell tumorigenesis. Mol. Cancer 2018, 17, 166. [CrossRef]

19. Liu, Y.Y.; Zhang, L.Y.; Du, W.Z. Circular RNA circ-PVT1 contributes to paclitaxel resistance of gastric cancer cells through the regulation of ZEB1 expression by sponging miR-124-3p. Biosci. Rep. 2019, 39, BSR20193045. [CrossRef]

20. Zhang, S.; Liu, Y.; Liu, Z.; Zhang, Y.; Chen, G.; Li, K.; Tang, K. CircRNA_0000502 promotes hepatocellular carcinoma metastasis and inhibits apoptosis through targeting microRNA-124. J. BUON 2019, 24, 2402-2410.

21. Cui, W.; Xue, J. Circular RNA DOCK1 downregulates microRNA-124 to induce the growth of human thyroid cancer cell lines Biofactors 2020, 46, 591-599. [CrossRef]

22. Sha, J.; Xia, L.; Han, Q.; Chi, C.; Zhu, Y.; Pan, J.; Huang, Y.; Xia, W.; Dong, B.; Xue, W.; et al. Downregulation of circ-TRPS1 suppressed prostatic cancer prognoses by regulating miR-124-3p/EZH2 axis-mediated stemness. Am. J. Cancer Res. 2020, 10, 4372-4385. [PubMed]

23. Yang, X.; Wang, J.; Li, H.; Sun, Y.; Tong, X. Downregulation of hsa_circ_0026123 suppresses ovarian cancer cell metastasis and proliferation through the miR-124-3p/EZH2 signaling pathway. Int. J. Mol. Med. 2021, 47, 668-676. [CrossRef] [PubMed]

24. Chen, G.; Shi, Y.; Liu, M.; Sun, J. circHIPK3 regulates cell proliferation and migration by sponging miR-124 and regulating AQP3 expression in hepatocellular carcinoma. Cell Death Dis. 2018, 9, 175. [CrossRef] [PubMed]

25. Hu, D.; Zhang, Y. Circular RNA HIPK3 promotes glioma progression by binding to miR-124-3p. Gene 2019, 690, 81-89. [CrossRef] [PubMed]

26. Liu, Z.; Guo, S.; Sun, H.; Bai, Y.; Song, Z.; Liu, X. Circular RNA CircHIPK3 Elevates CCND2 Expression and Promotes Cell Proliferation and Invasion Through miR-124 in Glioma. Front. Genet. 2020, 11, 1013. [CrossRef]

27. Xia, L.; Yi, F.; Zhai, X.; Zhang, M. Circular RNA homeodomain-interacting protein kinase 3 (circHIPK3) promotes growth and metastasis of glioma cells by sponging miR-124-3p. Xi Bao Yu Fen Zi Mian Yi Xue Za Zhi 2020, 36, 609-615. [PubMed]

28. Yu, H.; Chen, Y.; Jiang, P. Circular RNA HIPK3 exerts oncogenic properties through suppression of miR-124 in lung cancer. Biochem. Biophys. Res. Commun. 2018, 506, 455-462. [CrossRef]

29. Cheng, J.; Zhuo, H.; Xu, M.; Wang, L.; Xu, H.; Peng, J.; Hou, J.; Lin, L.; Cai, J. Regulatory network of circRNA-miRNA-mRNA contributes to the histological classification and disease progression in gastric cancer. J. Transl. Med. 2018, 16, 216. [CrossRef]

30. Kai, D.; Yannian, L.; Yitian, C.; Dinghao, G.; Xin, Z.; Wu, J. Circular RNA HIPK3 promotes gallbladder cancer cell growth by sponging microRNA-124. Biochem. Biophys. Res. Commun. 2018, 503, 863-869. [CrossRef]

31. Wang, J.; Zhao, S.Y.; Ouyang, S.S.; Huang, Z.K.; Luo, Q.; Liao, L. Circular RNA circHIPK3 acts as the sponge of microRNA-124 to promote human oral squamous cell carcinoma cells proliferation. Zhonghua Kou Qiang Yi Xue Za Zhi 2018, 53, 546-551. [PubMed]

32. Li, S.; Mei, Z.; Hu, H.B.; Zhang, X. The lncRNA MALAT1 contributes to non-small cell lung cancer development via modulating miR-124/STAT3 axis. J. Cell Physiol. 2018, 233, 6679-6688. [CrossRef] [PubMed]

33. Wu, J.; Weng, Y.; He, F.; Liang, D.; Cai, L. LncRNA MALAT-1 competitively regulates miR-124 to promote EMT and development of non-small-cell lung cancer. Anticancer Drugs 2018, 29, 628-636. [CrossRef] [PubMed]

34. Liu, S.; Song, L.; Zeng, S.; Zhang, L. MALAT1-miR-124-RBG2 axis is involved in growth and invasion of HR-HPV-positive cervical cancer cells. Tumour Biol. 2016, 37, 633-640. [CrossRef]

35. Shi, B.; Wang, Y.; Yin, F. MALAT1/miR-124/Capn4 axis regulates proliferation, invasion and EMT in nasopharyngeal carcinoma cells. Cancer Biol. Ther. 2017, 18, 792-800. [CrossRef] [PubMed]

36. Li, D.; Chen, P.; Li, X.Y.; Zhang, L.Y.; Xiong, W.; Zhou, M.; Xiao, L.; Zeng, F.; Li, X.L.; Wu, M.H.; et al. Grade-specific expression profiles of miRNAs/mRNAs and docking study in human grade I-III astrocytomas. OMICS 2011, 15, 673-682. [CrossRef]

37. Lv, Z.; Yang, L. MiR-124 inhibits the growth of glioblastoma through the downregulation of SOS1. Mol. Med. Rep. 2013, 8, 345-349. [CrossRef]

38. Silber, J.; Hashizume, R.; Felix, T.; Hariono, S.; Yu, M.; Berger, M.S.; Huse, J.T.; VandenBerg, S.R.; James, C.D.; Hodgson, J.G.; et al. Expression of miR-124 inhibits growth of medulloblastoma cells. Neuro-oncology 2013, 15, 83-90. [CrossRef]

39. Wei, J.; Wang, F.; Kong, L.Y.; Xu, S.; Doucette, T.; Ferguson, S.D.; Yang, Y.; McEnery, K.; Jethwa, K.; Gjyshi, O.; et al. miR-124 inhibits STAT3 signaling to enhance T cell-mediated immune clearance of glioma. Cancer Res. 2013, 73, 3913-3926. [CrossRef]

40. Zhao, W.H.; Wu, S.Q.; Zhang, Y.D. Downregulation of miR-124 promotes the growth and invasiveness of glioblastoma cells involving upregulation of PPP1R13L. Int. J. Mol. Med. 2013, 32, 101-107. [CrossRef]

41. Mucaj, V.; Lee, S.S.; Skuli, N.; Giannoukos, D.N.; Qiu, B.; Eisinger-Mathason, T.S.; Nakazawa, M.S.; Shay, J.E.; Gopal, P.P.; Venneti, S.; et al. MicroRNA-124 expression counteracts pro-survival stress responses in glioblastoma. Oncogene 2015, 34, 2204-2214. [CrossRef]

42. Cai, J.J.; Qi, Z.X.; Chen, L.C.; Yao, Y.; Gong, Y.; Mao, Y. miR-124 suppresses the migration and invasion of glioma cells in vitro via Capn4. Oncol. Rep. 2016, 35, 284-290. [CrossRef]

43. Deng, D.; Wang, L.; Chen, Y.; Li, B.; Xue, L.; Shao, N.; Wang, Q.; Xia, X.; Yang, Y.; Zhi, F. MicroRNA-124-3p regulates cell proliferation, invasion, apoptosis, and bioenergetics by targeting PIM1 in astrocytoma. Cancer Sci. 2016, 107, 899-907. [CrossRef]

44. Marisetty, A.L.; Singh, S.K.; Nguyen, T.N.; Coarfa, C.; Liu, B.; Majumder, S. REST represses miR-124 and miR-203 to regulate distinct oncogenic properties of glioblastoma stem cells. Neuro-oncology 2017, 19, 514-523. [CrossRef] [PubMed] 
45. Qiao, W.; Guo, B.; Zhou, H.; Xu, W.; Chen, Y.; Liang, Y.; Dong, B. miR-124 suppresses glioblastoma growth and potentiates chemosensitivity by inhibiting AURKA. Biochem. Biophys. Res. Commun. 2017, 486, 43-48. [CrossRef] [PubMed]

46. Lin, J.; Wen, X.; Zhang, X.; Sun, X.; Yunzhi, L.; Peng, R.; Zhu, M.; Wang, M.; Zhang, Y.; Luo, W.; et al. miR-135a-5p and miR-124-3p Inhibit Malignancy of Glioblastoma by Downregulation of Syndecan Binding Protein. J. Biomed. Nanotechnol. 2018, 14, 1317-1329. [CrossRef] [PubMed]

47. Liu, X.; Kang, J.; Sun, S.; Luo, Y.; Ji, X.; Zeng, X.; Zhao, S. iASPP, a microRNA124 target, is aberrantly expressed in astrocytoma and regulates malignant glioma cell migration and viability. Mol. Med. Rep. 2018, 17, 1970-1978. [PubMed]

48. Sharif, S.; Ghahremani, M.H.; Soleimani, M. Delivery of Exogenous miR-124 to Glioblastoma Multiform Cells by Wharton's Jelly Mesenchymal Stem Cells Decreases Cell Proliferation and Migration, and Confers Chemosensitivity. Stem Cell Rev. Rep. 2018, 14, 236-246. [CrossRef]

49. Zhang, G.; Chen, L.; Khan, A.A.; Li, B.; Gu, B.; Lin, F.; Su, X.; Yan, J. miRNA-124-3p/neuropilin-1(NRP-1) axis plays an important role in mediating glioblastoma growth and angiogenesis. Int. J. Cancer 2018, 143, 635-644. [CrossRef]

50. Bhaskaran, V.; Nowicki, M.O.; Idriss, M.; Jimenez, M.A.; Lugli, G.; Hayes, J.L.; Mahmoud, A.B.; Zane, R.E.; Passaro, C.; Ligon, K.L.; et al. The functional synergism of microRNA clustering provides therapeutically relevant epigenetic interference in glioblastoma. Nat. Commun. 2019, 10, 442. [CrossRef]

51. Deng, X.; Ma, L.; Wu, M.; Zhang, G.; Jin, C.; Guo, Y.; Liu, R. miR-124 radiosensitizes human glioma cells by targeting CDK4. J. Neurooncol. 2013, 114, 263-274. [CrossRef] [PubMed]

52. Hirose, Y.; Ohb, S. Biological Responses of Glioma Cell to Chemotherapeutic Agents. In Advances in the Biology, Imaging and Therapies for Glioblastoma; IntechOpen: London, UK, 2011; pp. 61-76. ISBN 978-953-307-284-5.

53. Kumar, M.S.; Lu, J.; Mercer, K.L.; Golub, T.R.; Jacks, T. Impaired microRNA processing enhances cellular transformation and tumorigenesis. Nat. Genet. 2007, 39, 673-677. [CrossRef]

54. Wang, D.; Zhang, H.; Li, M.; Frid, M.G.; Flockton, A.R.; McKeon, B.A.; Yeager, M.E.; Fini, M.A.; Morrell, N.W.; Pullamsetti, S.S.; et al. MicroRNA-124 controls the proliferative, migratory, and inflammatory phenotype of pulmonary vascular fibroblasts. Circ. Res. 2014, 114, 67-78. [CrossRef] [PubMed]

55. Li, X.; Yu, Z.; Li, Y.; Liu, S.; Gao, C.; Hou, X.; Yao, R.; Cui, L. The tumor suppressor miR-124 inhibits cell proliferation by targeting STAT3 and functions as a prognostic marker for postoperative NSCLC patients. Int. J. Oncol. 2015, 46, 798-808. [CrossRef] [PubMed]

56. Cui, Z.; Hu, Y. MicroRNA-124 suppresses Slug-mediated lung cancer metastasis. Eur. Rev. Med. Pharmacol. Sci. 2016, $20,3802-3811$.

57. Li, Z.; Wang, X.; Li, W.; Wu, L.; Chang, L.; Chen, H. miRNA-124 modulates lung carcinoma cell migration and invasion. Int. J. Clin. Pharmacol. Ther. 2016, 54, 603-612. [CrossRef] [PubMed]

58. Lin, J.; Xu, K.; Wei, J.; Heimberger, A.B.; Roth, J.A.; Ji, L. MicroRNA-124 suppresses tumor cell proliferation and invasion by targeting CD164 signaling pathway in non-small cell lung cancer. J. Gene. Ther. 2016, 2, 6.

59. Mehta, A.K.; Hua, K.; Whipple, W.; Nguyen, M.T.; Liu, C.T.; Haybaeck, J.; Weidhaas, J.; Settleman, J.; Singh, A. Regulation of autophagy, NF-kappaB signaling, and cell viability by miR-124 in KRAS mutant mesenchymal-like NSCLC cells. Sci. Signal. 2017, 10, eaam6291. [CrossRef]

60. Zhao, X.; Lu, C.; Chu, W.; Zhang, B.; Zhen, Q.; Wang, R.; Zhang, Y.; Li, Z.; Lv, B.; Li, H.; et al. MicroRNA-124 suppresses proliferation and glycolysis in non-small cell lung cancer cells by targeting AKT-GLUT1/HKII. Tumour Biol. 2017, 39, 1010428317706215. [CrossRef]

61. Sun, Y.; Ai, X.; Shen, S.; Lu, S. NF-kappaB-mediated miR-124 suppresses metastasis of non-small-cell lung cancer by targeting MYO10. Oncotarget 2015, 6, 8244-8254. [CrossRef]

62. Hao, C.; Xu, X.; Ma, J.; Xia, J.; Dai, B.; Liu, L.; Ma, Y. MicroRNA-124 regulates the radiosensitivity of non-small cell lung cancer cells by targeting TXNRD1. Oncol. Lett. 2017, 13, 2071-2078. [CrossRef]

63. Wang, M.; Meng, B.; Liu, Y.; Yu, J.; Chen, Q.; Liu, Y. MiR-124 Inhibits Growth and Enhances Radiation-Induced Apoptosis in Non-Small Cell Lung Cancer by Inhibiting STAT3. Cell Physiol. Biochem. 2017, 44, 2017-2028. [CrossRef]

64. Yang, Q.; Wan, L.; Xiao, C.; Hu, H.; Wang, L.; Zhao, J.; Lei, Z.; Zhang, H.T. Inhibition of LHX2 by miR-124 suppresses cellular migration and invasion in non-small cell lung cancer. Oncol. Lett. 2017, 14, 3429-3436. [CrossRef] [PubMed]

65. Qi, M.M.; Ge, F.; Chen, X.J.; Tang, C.; Ma, J. MiR-124 changes the sensitivity of lung cancer cells to cisplatin through targeting STAT3. Eur. Rev. Med. Pharmacol. Sci. 2019, 23, 5242-5250.

66. Liu, T.; Zhu, J.; Du, W.; Ning, W.; Zhang, Y.; Zeng, Y.; Liu, Z.; Huang, J.A. AKT2 drives cancer progression and is negatively modulated by miR-124 in human lung adenocarcinoma. Respir. Res. 2020, 21, 227. [CrossRef] [PubMed]

67. Wu, J.; Li, L.; Zhang, Y.; Zhu, J. Decreased miR-124 contributes to the epithelial-mesenchymal transition phenotype formation of lung adenocarcinoma cells via targeting enhancer of zeste homolog 2. Pathol. Res. Pract. 2020, 216, 152976. [CrossRef] [PubMed]

68. Ma, T.; Zhao, Y.; Wei, K.; Yao, G.; Pan, C.; Liu, B.; Xia, Y.; He, Z.; Qi, X.; Li, Z.; et al. MicroRNA-124 Functions as a Tumor Suppressor by Regulating CDH2 and Epithelial-Mesenchymal Transition in Non-Small Cell Lung Cancer. Cell Physiol. Biochem. 2016, 38, 1563-1574. [CrossRef]

69. Park, S.Y.; Kim, H.; Yoon, S.; Bae, J.A.; Choi, S.Y.; Jung, Y.D.; Kim, K.K. KITENIN-targeting microRNA-124 suppresses colorectal cancer cell motility and tumorigenesis. Mol. Ther. 2014, 22, 1653-1664. [CrossRef]

70. Zhou, L.; Xu, Z.; Ren, X.; Chen, K.; Xin, S. MicroRNA-124 (MiR-124) Inhibits Cell Proliferation, Metastasis and Invasion in Colorectal Cancer by Downregulating Rho-Associated Protein Kinase 1(ROCK1). Cell Physiol. Biochem. 2016, 38, 1785-1795. [CrossRef] [PubMed] 
71. Liu, K.; Yao, H.; Lei, S.; Xiong, L.; Qi, H.; Qian, K.; Liu, J.; Wang, P.; Zhao, H. The miR-124-p63 feedback loop modulates colorectal cancer growth. Oncotarget 2017, 8, 29101-29115. [CrossRef] [PubMed]

72. Taniguchi, K.; Sugito, N.; Kumazaki, M.; Shinohara, H.; Yamada, N.; Nakagawa, Y.; Ito, Y.; Otsuki, Y.; Uno, B.; Uchiyama, K.; et al. MicroRNA-124 inhibits cancer cell growth through PTB1/PKM1/PKM2 feedback cascade in colorectal cancer. Cancer Lett. 2015, 363, 17-27. [CrossRef] [PubMed]

73. Gatenby, R.A.; Gillies, R.J. Why do cancers have high aerobic glycolysis? Nat. Rev. Cancer 2004, 4, 891-899. [CrossRef] [PubMed]

74. Taniguchi, K.; Sugito, N.; Kumazaki, M.; Shinohara, H.; Yamada, N.; Matsuhashi, N.; Futamura, M.; Ito, Y.; Otsuki, Y.; Yoshida, K.; et al. Positive feedback of DDX6/c-Myc/PTB1 regulated by miR-124 contributes to maintenance of the Warburg effect in colon cancer cells. Biochim. Biophys. Acta 2015, 1852, 1971-1980. [CrossRef]

75. Li, M.; Wan, G.; Yu, H.; Xiong, W. High-intensity focused ultrasound inhibits invasion and metastasis of colon cancer cells by enhancing microRNA-124-mediated suppression of STAT3. FEBS Open Bio 2019, 9, 1128-1136. [CrossRef]

76. Zhang, J.; Lu, Y.; Yue, X.; Li, H.; Luo, X.; Wang, Y.; Wang, K.; Wan, J. MiR-124 suppresses growth of human colorectal cancer by inhibiting STAT3. PLOS ONE 2013, 8, e70300. [CrossRef] [PubMed]

77. Furuta, M.; Kozaki, K.I.; Tanaka, S.; Arii, S.; Imoto, I.; Inazawa, J. miR-124 and miR-203 are epigenetically silenced tumorsuppressive microRNAs in hepatocellular carcinoma. Carcinogenesis 2010, 31, 766-776. [CrossRef]

78. Lang, Q.; Ling, C. MiR-124 suppresses cell proliferation in hepatocellular carcinoma by targeting PIK3CA. Biochem. Biophys. Res. Commun. 2012, 426, 247-252. [CrossRef] [PubMed]

79. Zheng, F.; Liao, Y.J.; Cai, M.Y.; Liu, Y.H.; Liu, T.H.; Chen, S.P.; Bian, X.W.; Guan, X.Y.; Lin, M.C.; Zeng, Y.X.; et al. The putative tumour suppressor microRNA-124 modulates hepatocellular carcinoma cell aggressiveness by repressing ROCK2 and EZH2. Gut 2012, 61, 278-289. [CrossRef]

80. Lu, Y.; Yue, X.; Cui, Y.; Zhang, J.; Wang, K. MicroRNA-124 suppresses growth of human hepatocellular carcinoma by targeting STAT3. Biochem. Biophys. Res. Commun. 2013, 441, 873-879. [CrossRef]

81. Xu, L.; Dai, W.; Li, J.; He, L.; Wang, F.; Xia, Y.; Chen, K.; Li, S.; Liu, T.; Lu, J.; et al. Methylation-regulated miR-124-1 suppresses tumorigenesis in hepatocellular carcinoma by targeting CASC3. Oncotarget 2016, 7, 26027-26041. [CrossRef]

82. Cai, Q.Q.; Dong, Y.W.; Wang, R.; Qi, B.; Guo, J.X.; Pan, J.; Liu, Y.Y.; Zhang, C.Y.; Wu, X.Z. MiR-124 inhibits the migration and invasion of human hepatocellular carcinoma cells by suppressing integrin alphaV expression. Sci. Rep. 2017, 7, 40733. [CrossRef] [PubMed]

83. Yue, X.; Cui, Y.; You, Q.; Lu, Y.; Zhang, J. MicroRNA124 negatively regulates chloride intracellular channel 1 to suppress the migration and invasion of liver cancer cells. Oncol. Rep. 2019, 42, 1380-1390. [PubMed]

84. Xia, J.; Wu, Z.; Yu, C.; He, W.; Zheng, H.; He, Y.; Jian, W.; Chen, L.; Zhang, L.; Li, W. miR-124 inhibits cell proliferation in gastric cancer through down-regulation of SPHK1. J. Pathol. 2012, 227, 470-480. [CrossRef] [PubMed]

85. Xie, L.M.; He, R.F.; Zhang, Z.W.; Tang, Y.Y.; Luo, Z.Y. miR-124 suppresses cell proliferation and invasion in gastric carcinoma and its mechanism. Zhonghua Zhong Liu Za Zhi 2013, 35, 497-500. [PubMed]

86. Hu, C.B.; Li, Q.L.; Hu, J.F.; Zhang, Q.; Xie, J.P.; Deng, L. miR-124 inhibits growth and invasion of gastric cancer by targeting ROCK1. Asian Pac. J. Cancer Prev. 2014, 15, 6543-6546. [CrossRef]

87. Xie, L.; Zhang, Z.; Tan, Z.; He, R.; Zeng, X.; Xie, Y.; Li, S.; Tang, G.; Tang, H.; He, X. MicroRNA-124 inhibits proliferation and induces apoptosis by directly repressing EZH2 in gastric cancer. Mol. Cell Biochem. 2014, 392, 153-159. [CrossRef]

88. Pan, Y.; Wu, A.; Xu, F.; Chen, C.; Jiang, L.; Jin, R. Lentivirus-mediated overexpression of miR-124 suppresses growth and invasion by targeting JAG1 and EZH2 in gastric cancer. Oncol. Lett. 2018, 15, 7450-7458. [CrossRef]

89. Lv, X.B.; Jiao, Y.; Qing, Y.; Hu, H.; Cui, X.; Lin, T.; Song, E.; Yu, F. miR-124 suppresses multiple steps of breast cancer metastasis by targeting a cohort of pro-metastatic genes in vitro. Chin. J. Cancer 2011, 30, 821-830. [CrossRef]

90. Han, Z.B.; Yang, Z.; Chi, Y.; Zhang, L.; Wang, Y.; Ji, Y.; Wang, J.; Zhao, H.; Han, Z.C. MicroRNA-124 suppresses breast cancer cell growth and motility by targeting CD151. Cell Physiol. Biochem. 2013, 31, 823-832. [CrossRef]

91. Li, L.; Luo, J.; Wang, B.; Wang, D.; Xie, X.; Yuan, L.; Guo, J.; Xi, S.; Gao, J.; Lin, X.; et al. Microrna-124 targets flotillin-1 to regulate proliferation and migration in breast cancer. Mol. Cancer 2013, 12, 163. [CrossRef] [PubMed]

92. Liang, Y.J.; Wang, Q.Y.; Zhou, C.X.; Yin, Q.Q.; He, M.; Yu, X.T.; Cao, D.X.; Chen, G.Q.; He, J.R.; Zhao, Q. MiR-124 targets Slug to regulate epithelial-mesenchymal transition and metastasis of breast cancer. Carcinogenesis 2013, 34, 713-722. [CrossRef]

93. Feng, T.; Xu, D.; Tu, C.; Li, W.; Ning, Y.; Ding, J.; Wang, S.; Yuan, L.; Xu, N.; Qian, K.; et al. MiR-124 inhibits cell proliferation in breast cancer through downregulation of CDK4. Tumour Biol. 2015, 36, 5987-5997. [CrossRef] [PubMed]

94. Jiang, C.F.; Li, D.M.; Shi, Z.M.; Wang, L.; Liu, M.M.; Ge, X.; Liu, X.; Qian, Y.C.; Wen, Y.Y.; Zhen, L.L.; et al. Estrogen regulates miRNA expression: Implication of estrogen receptor and miR-124/AKT2 in tumor growth and angiogenesis. Oncotarget 2016, 7, 36940-36955. [CrossRef] [PubMed]

95. Wang, Y.; Chen, L.; Wu, Z.; Wang, M.; Jin, F.; Wang, N.; Hu, X.; Liu, Z.; Zhang, C.Y.; Zen, K.; et al. miR-124-3p functions as a tumor suppressor in breast cancer by targeting CBL. BMC Cancer 2016, 16, 826. [CrossRef] [PubMed]

96. Cai, W.L.; Huang, W.D.; Li, B.; Chen, T.R.; Li, Z.X.; Zhao, C.L.; Li, H.Y.; Wu, Y.M.; Yan, W.J.; Xiao, J.R. microRNA-124 inhibits bone metastasis of breast cancer by repressing Interleukin-11. Mol. Cancer 2018, 17, 9. [CrossRef] [PubMed]

97. Shi, P.; Chen, C.; Li, X.; Wei, Z.; Liu, Z.; Liu, Y. MicroRNA124 suppresses cell proliferation and invasion of triple negative breast cancer cells by targeting STAT3. Mol. Med. Rep. 2019, 19, 3667-3675.

98. Ji, H.; Sang, M.; Liu, F.; Ai, N.; Geng, C. miR-124 regulates EMT based on ZEB2 target to inhibit invasion and metastasis in triple-negative breast cancer. Pathol. Res. Pract. 2019, 215, 697-704. [CrossRef] 
99. Goltzman, D. Osteolysis and cancer. J. Clin. Investig. 2001, 107, 1219-1220. [CrossRef]

100. Liu, C.; Xing, H.; Guo, C.; Yang, Z.; Wang, Y.; Wang, Y. MiR-124 reversed the doxorubicin resistance of breast cancer stem cells through STAT3/HIF-1 signaling pathways. Cell Cycle 2019, 18, 2215-2227. [CrossRef] [PubMed]

101. Li, Y.; Zhang, Z.; Liu, X.; Huang, T.; He, W.; Shen, Y.; Liu, X.; Hong, K.; Cao, Q. miR-124 functions as a tumor suppressor in the endometrial carcinoma cell line HEC-1B partly by suppressing STAT3. Mol. Cell Biochem. 2014, 388, 219-231. [CrossRef]

102. Cheng, Y.; Li, Y.; Nian, Y.; Liu, D.; Dai, F.; Zhang, J. STAT3 is involved in miR-124-mediated suppressive effects on esophageal cancer cells. BMC Cancer 2015, 15, 306. [CrossRef]

103. Li, Z.; Qin, X.; Bian, W.; Li, Y.; Shan, B.; Yao, Z.; Li, S. Exosomal lncRNA ZFAS1 regulates esophageal squamous cell carcinoma cell proliferation, invasion, migration and apoptosis via microRNA-124/STAT3 axis. J. Exp. Clin. Cancer Res. 2019, 38, 477. [CrossRef]

104. Xu, S.; Zhao, N.; Hui, L.; Song, M.; Miao, Z.W.; Jiang, X.J. MicroRNA-124-3p inhibits the growth and metastasis of nasopharyngeal carcinoma cells by targeting STAT3. Oncol. Rep. 2016, 35, 1385-1394. [CrossRef]

105. Liu, S.; Hu, C.; Wang, Y.; Shi, G.; Li, Y.; Wu, H. miR-124 inhibits proliferation and invasion of human retinoblastoma cells by targeting STAT3. Oncol. Rep. 2016, 36, 2398-2404. [CrossRef]

106. Wu, Z.; Huang, W.; Chen, B.; Bai, P.D.; Wang, X.G.; Xing, J.C. Up-regulation of miR-124 inhibits invasion and proliferation of prostate cancer cells through mediating JAK-STAT3 signaling pathway. Eur. Rev. Med. Pharmacol. Sci. 2020, $24,7546$.

107. Ma, J.; Weng, L.; Wang, Z.; Jia, Y.; Liu, B.; Wu, S.; Cao, Y.; Sun, X.; Yin, X.; Shang, M.; et al. MiR-124 induces autophagy-related cell death in cholangiocarcinoma cells through direct targeting of the EZH2-STAT3 signaling axis. Exp. Cell Res. 2018, 366, 103-113. [CrossRef]

108. Zheng, Y.B.; Xiao, G.C.; Tong, S.L.; Ding, Y.; Wang, Q.S.; Li, S.B.; Hao, Z.N. Paeoniflorin inhibits human gastric carcinoma cell proliferation through up-regulation of microRNA-124 and suppression of PI3K/Akt and STAT3 signaling. World J. Gastroenterol. 2015, 21, 7197-7207. [CrossRef]

109. Lee, H.; Herrmann, A.; Deng, J.H.; Kujawski, M.; Niu, G.; Li, Z.; Forman, S.; Jove, R.; Pardoll, D.M.; Yu, H. Persistently activated Stat3 maintains constitutive NF-kappaB activity in tumors. Cancer Cell 2009, 15, 283-293. [CrossRef] [PubMed]

110. Frank, D.A. STAT3 as a central mediator of neoplastic cellular transformation. Cancer Lett. 2007, 251, 199-210. [CrossRef] [PubMed]

111. Kamran, M.Z.; Patil, P.; Gude, R.P. Role of STAT3 in cancer metastasis and translational advances. Biomed. Res. Int. 2013, 2013, 421821. [CrossRef] [PubMed]

112. Ahmed-Choudhury, J.; Williams, K.T.; Young, L.S.; Adams, D.H.; Afford, S.C. CD40 mediated human cholangiocyte apoptosis requires JAK2 dependent activation of STAT3 in addition to activation of JNK1/2 and ERK1/2. Cell Signal. 2006, 18, 456-468. [CrossRef]

113. de la Iglesia, N.; Konopka, G.; Puram, S.V.; Chan, J.A.; Bachoo, R.M.; You, M.J.; Levy, D.E.; Depinho, R.A.; Bonni, A. Identification of a PTEN-regulated STAT3 brain tumor suppressor pathway. Genes Dev. 2008, 22, 449-462. [CrossRef]

114. Xiao, D.; Cui, X.; Wang, X. Long noncoding RNA XIST increases the aggressiveness of laryngeal squamous cell carcinoma by regulating miR-124-3p/EZH2. Exp. Cell Res. 2019, 381, 172-178. [CrossRef]

115. Sabour Takanlu, J.; Aghaie Fard, A.; Mohammdi, S.; Hosseini Rad, S.M.A.; Abroun, S.; Nikbakht, M. Indirect Tumor Inhibitory Effects of MicroRNA-124 through Targeting EZH2 in The Multiple Myeloma Cell Line. Cell J. 2020, 22, $23-29$.

116. Bracken, A.P.; Pasini, D.; Capra, M.; Prosperini, E.; Colli, E.; Helin, K. EZH2 is downstream of the pRB-E2F pathway, essential for proliferation and amplified in cancer. EMBO J. 2003, 22, 5323-5335. [CrossRef] [PubMed]

117. Tiwari, N.; Tiwari, V.K.; Waldmeier, L.; Balwierz, P.J.; Arnold, P.; Pachkov, M.; Meyer-Schaller, N.; Schubeler, D.; van Nimwegen, E.; Christofori, G. Sox 4 is a master regulator of epithelial-mesenchymal transition by controlling Ezh2 expression and epigenetic reprogramming. Cancer Cell 2013, 23, 768-783. [CrossRef] [PubMed]

118. Papagiannakopoulos, T.; Kosik, K.S. MicroRNA-124: Micromanager of neurogenesis. Cell Stem Cell 2009, 4, 375-376. [CrossRef] [PubMed]

119. Tuttle, M.; Dalman, M.R.; Liu, Q.; Londraville, R.L. Leptin-a mediates transcription of genes that participate in central endocrine and phosphatidylinositol signaling pathways in 72-hour embryonic zebrafish (Danio rerio). PeerJ 2019, 7, e6848. [CrossRef]

120. Neo, W.H.; Yap, K.; Lee, S.H.; Looi, L.S.; Khandelia, P.; Neo, S.X.; Makeyev, E.V.; Su, I.H. MicroRNA miR-124 controls the choice between neuronal and astrocyte differentiation by fine-tuning Ezh2 expression. J. Biol. Chem. 2014, 289, 20788-20801. [CrossRef] [PubMed]

121. Suzuki, F.; Okuno, M.; Tanaka, T.; Sanuki, R. Overexpression of neural miRNAs miR-9/9* and miR-124 suppresses differentiation to Muller glia and promotes differentiation to neurons in mouse retina in vivo. Genes Cells 2020, 25, 741-752. [CrossRef] [PubMed]

122. Yoo, A.S.; Sun, A.X.; Li, L.; Shcheglovitov, A.; Portmann, T.; Li, Y.; Lee-Messer, C.; Dolmetsch, R.E.; Tsien, R.W.; Crabtree, G.R. MicroRNA-mediated conversion of human fibroblasts to neurons. Nature 2011, 476, 228-231. [CrossRef] [PubMed]

123. Lee, S.W.; Oh, Y.M.; Lu, Y.L.; Kim, W.K.; Yoo, A.S. MicroRNAs Overcome Cell Fate Barrier by Reducing EZH2-Controlled REST Stability during Neuronal Conversion of Human Adult Fibroblasts. Dev. Cell 2018, 46, 73-84. [CrossRef] [PubMed]

124. Xue, Y.; Ouyang, K.; Huang, J.; Zhou, Y.; Ouyang, H.; Li, H.; Wang, G.; Wu, Q.; Wei, C.; Bi, Y.; et al. Direct conversion of fibroblasts to neurons by reprogramming PTB-regulated microRNA circuits. Cell 2013, 152, 82-96. [CrossRef] [PubMed]

125. Makeyev, E.V.; Zhang, J.; Carrasco, M.A.; Maniatis, T. The MicroRNA miR-124 promotes neuronal differentiation by triggering brain-specific alternative pre-mRNA splicing. Mol. Cell 2007, 27, 435-448. [CrossRef]

126. Mangale, V.S.; Hirokawa, K.E.; Satyaki, P.R.; Gokulchandran, N.; Chikbire, S.; Subramanian, L.; Shetty, A.S.; Martynoga, B.; Paul, J.; Mai, M.V.; et al. Lhx2 selector activity specifies cortical identity and suppresses hippocampal organizer fate. Science 2008, 319, 304-309. [CrossRef]

127. Wilson, S.I.; Shafer, B.; Lee, K.J.; Dodd, J. A molecular program for contralateral trajectory: Rig-1 control by LIM homeodomain transcription factors. Neuron 2008, 59, 413-424. [CrossRef] 
128. Subramanian, L.; Sarkar, A.; Shetty, A.S.; Muralidharan, B.; Padmanabhan, H.; Piper, M.; Monuki, E.S.; Bach, I.; Gronostajski, R.M.; Richards, L.J.; et al. Transcription factor Lhx2 is necessary and sufficient to suppress astrogliogenesis and promote neurogenesis in the developing hippocampus. Proc. Natl. Acad. Sci. USA 2011, 108, E265-E274. [CrossRef]

129. Franke, K.; Otto, W.; Johannes, S.; Baumgart, J.; Nitsch, R.; Schumacher, S. miR-124-regulated RhoG reduces neuronal process complexity via ELMO/Dock180/Rac1 and Cdc42 signalling. EMBO J. 2012, 31, 2908-2921. [CrossRef]

130. Swanwick, C.C.; Shapiro, M.E.; Vicini, S.; Wenthold, R.J. Flotillin-1 promotes formation of glutamatergic synapses in hippocampal neurons. Dev. Neurobiol. 2010, 70, 875-883. [CrossRef] [PubMed]

131. Averaimo, S.; Gritti, M.; Barini, E.; Gasparini, L.; Mazzanti, M. CLIC1 functional expression is required for cAMP-induced neurite elongation in post-natal mouse retinal ganglion cells. J. Neurochem. 2014, 131, 444-456. [CrossRef] [PubMed]

132. Newell-Litwa, K.A.; Badoual, M.; Asmussen, H.; Patel, H.; Whitmore, L.; Horwitz, A.R. ROCK1 and 2 differentially regulate actomyosin organization to drive cell and synaptic polarity. J. Cell Biol. 2015, 210, 225-242. [CrossRef] [PubMed]

133. Epifanova, E.; Babaev, A.; Newman, A.G.; Tarabykin, V. Role of Zeb2/Sip1 in neuronal development. Brain Res. 2019, 1705, 24-31. [CrossRef] [PubMed]

134. O'Neill, C.P.; Dwyer, R.M. Nanoparticle-Based Delivery of Tumor Suppressor microRNA for Cancer Therapy. Cells $2020,9,521$. [CrossRef] [PubMed] 